Original Paper http://ajol.info/index.php/ijbcs http://indexmedicus.afro.who.int

\title{
Inconvenience of traditional fishing practice on aquatic ecosystem of Nokoué Lake in Benin Republic (West Africa)
}

\author{
Bernadin ELEGBEDE MANOU ${ }^{1}$, Luc KOUMOLOU ${ }^{2 *}$, Flora F. N'TIA', \\ Mohamed I. ATIKOU ${ }^{1}$, Hervé E. LABITE ${ }^{1}$, Martin AINA ${ }^{1}$ and Patrick A. EDORH ${ }^{2}$ \\ ${ }^{I}$ Laboratoire des Sciences et Technique de l'Eau (LSTE), Département de Génie de l'Eau et Assainissement, \\ Institut National de l'Eau, Université d'Abomey-Calavi, 01 BP : 526 Cotonou, Bénin. \\ ${ }^{2}$ Laboratoire de Recherche en Biochimie et Toxicologie de l'Environnement (LaRBiTE). Faculté des Sciences et \\ Techniques (FAST), Université d'Abomey-Calavi, 01 BP : 526 Cotonou, Bénin. \\ "Corresponding author; E-mail: heraluc@yahoo.fr
}

\begin{abstract}
Located in coastal area of Benin, Nokoué Lake is the biggest lake in the West Africa due to his large surface $\left(120 \mathrm{~km}^{2}\right)$ and fishiness productivities. Unfortunately, it is faced with a lot of challenges due to traditional practice of fishing called "Acadja" and the management of every kind of waste. The objective of this study was to show Acadja's influence on the physico-chemical quality of the water in Nokoué Lake, and even on the future of the ecosystem and all associated activities. Three sampling taken from Acadja side and also three sampling taken from no Acadja side during dry season have been tested in temperature, $\mathrm{pH}$, dissolved oxygen, suspended solids, turbidity, level in $\mathrm{NO}^{3-}$ and $\mathrm{NO}^{2-}$, weight and length of fish. The analysis was made by spectrophotometer DR/2000 Hach, multipara meter wtw 340 and atomic absorption spectrophotometry for Toxic metals (lead). The result revealed that traditional system of fishing called Acadja influences almost of the physico-chemical parameters of the water and the fauna aquatic around the Acadja area. Therefore, this practice will threaten and disrupt food security of the habitants by reducing fish productivity. The sensitization sessions are required to lead local people to adhere to sustainable resource management.
\end{abstract}

(C) 2019 International Formulae Group. All rights reserved

Keywords: traditional fishing, water pollution, aquatic ecosystem, fish productivity.

\section{INTRODUCTION}

The largest in Benin and one of the largest in Africa, Lake Nokoué $\left(150 \mathrm{~km}^{2}\right)$ is a component of RAMSAR 1018 site of natural and cultural wealth unparalleled in the world. Located in southeast of Benin with geographical coordinates $6^{\circ} 25^{\prime} 60$ 'North and $2^{\circ} 27^{\prime} 06^{\prime}$ East, Lake Nokoué covers an area of approximately 339 ha. The shores of Lake Nokoué are occupied by the major urban centers of the country: Cotonou in the South, Abomey-Calavi in the West, and Sèmè Kpodji in the West. It communicates with Porto Novo through the lagoon of Porto Novo. It covers $150 \mathrm{~km}^{2}$ (Figure 1).

The lake is very important for the Benin development due to the important proportion of population in Benin whose survival depends on the lake. Thus, behind this lake, there is a big international market, Dantokpa market located in Cotonou, economic capital of Benin, where more than 100 tons of solid waste are produced per day (Amouzoun, 2009) and some were thrown in the lake. The lake is made up of a 

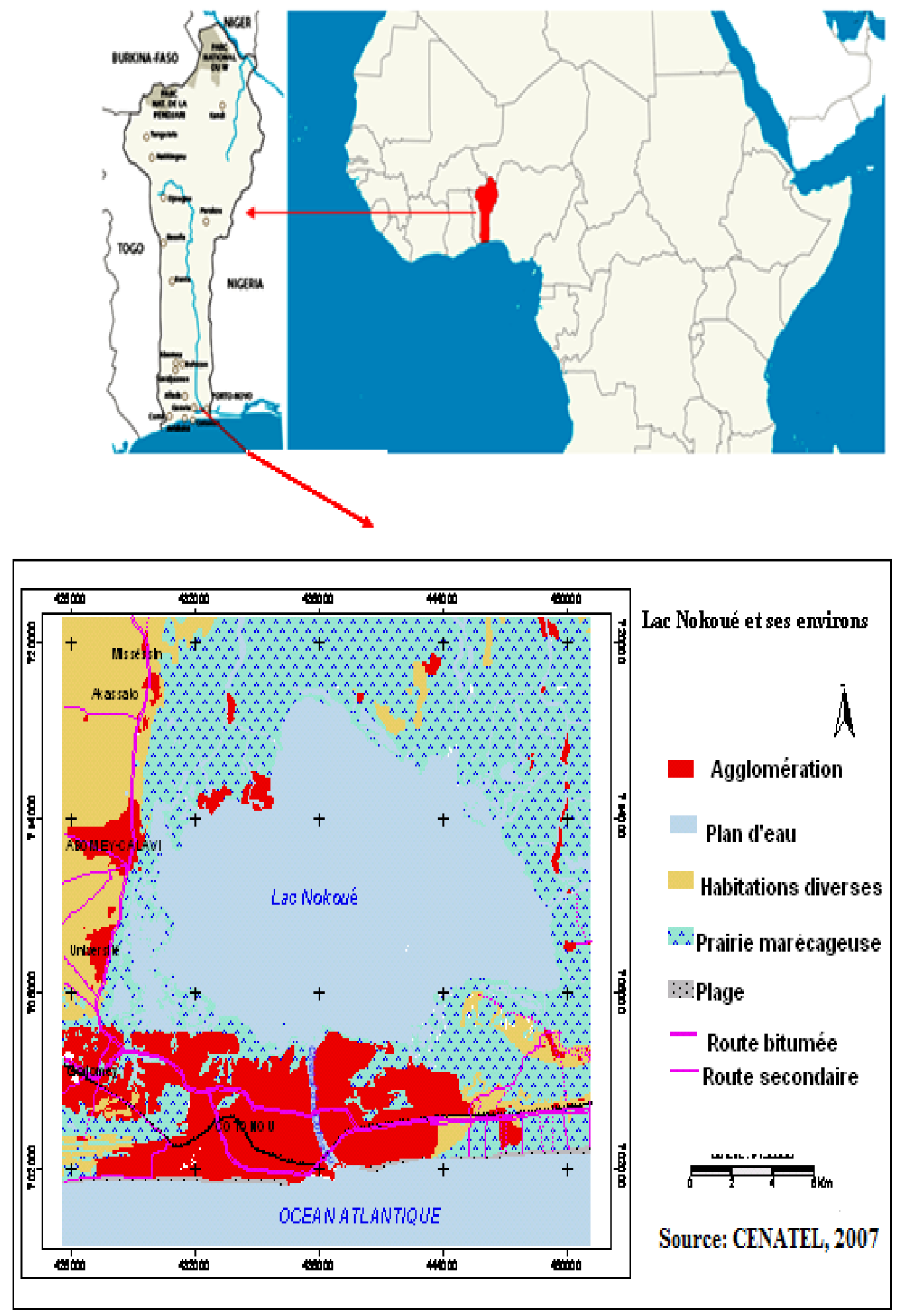

Figure 1: Map of Lake Nokoué (Dovonou, 2008). 
swampy complex that serves as a place of passage and refuge for traffickers of petroleum products and other smugglers but also for fishing and market gardening (Agonkpahoun, 2006). According to some studies, the maintenance of the pass since the construction of the port of Cotonou, uncontrolled dredging and fishing techniques Acadja practised by the Toffin populations of Ganvié and Zogbo (Figure 2).

This traditional fishing technique have largely modified the hydrodynamic, physicochemical and ecological conditions of the lake. Today, fishermen no longer earn substantial income from fishing because of reduced catch sizes and the market size of fish. Solid waste of terrestrial origin pollutes also the lake which drains them towards the sea by the channel. The objective of this study is to show Acadja's influence on the physicochemical quality of the water in Nokoué Lake, and even on the future of the ecosystem and all associated activities. The vulnerability of Nokoué Lake to pollution must be verified by the assessment of the influence of this traditional fishing technique on the physicochemical quality of some sampling water taken from the Lake.

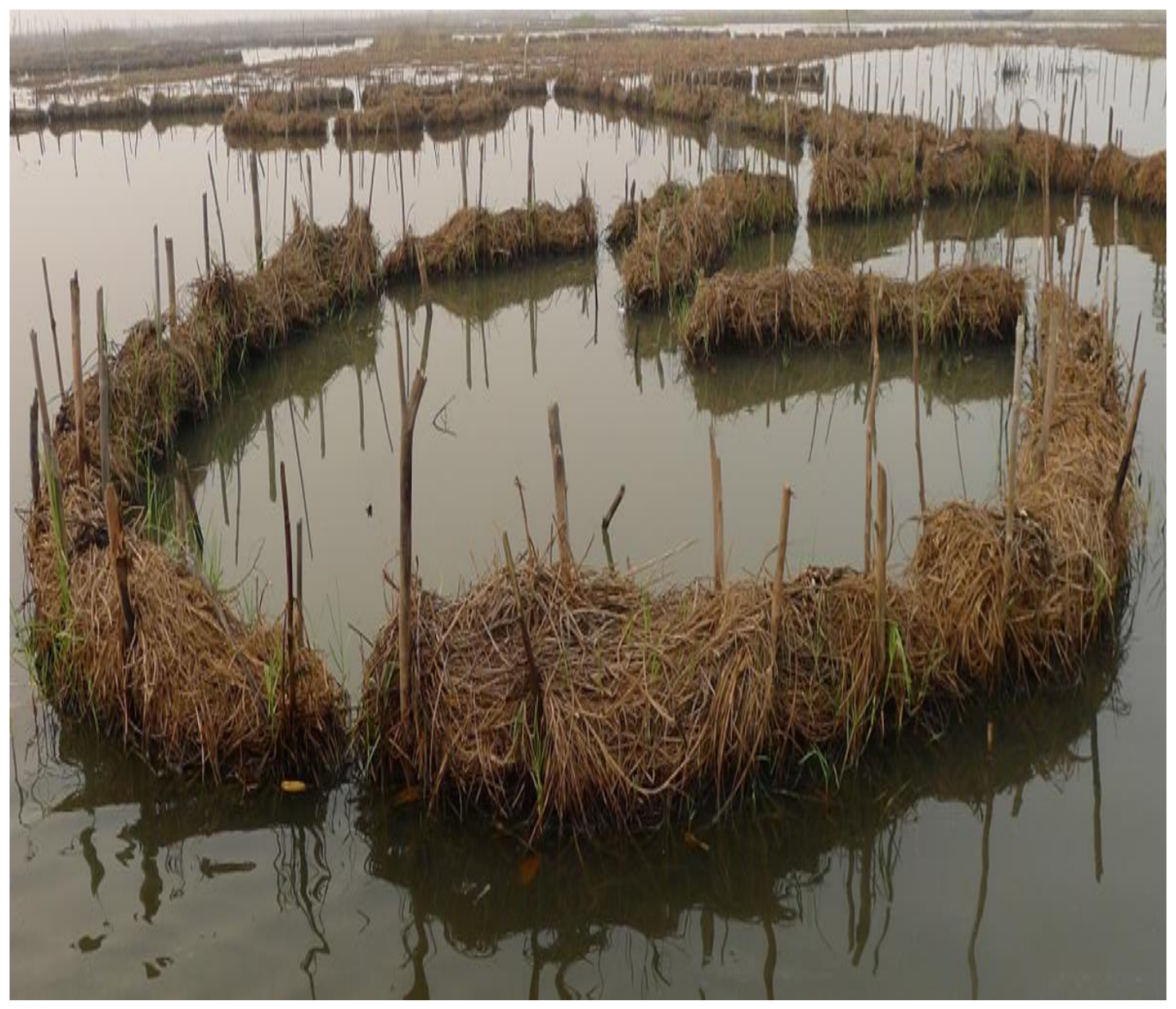

Figure 2: Acadja dispatched in Nokoué Lake (Djogbénou, 2019). 


\section{MATERIALS AND METHODS}

This study was carried out during dry season. Three samples taken from Acadja side and also three samples taken from no Acadja side were tested in temperature, $\mathrm{pH}$, dissolved oxygen, suspended solids, turbidity, level in $\mathrm{NO}_{3}{ }^{-}$and $\mathrm{NO}_{2}{ }^{-}$, weight and length of fish. The

\section{RESULTS}

The results are presented in Table 1 . Blot spot is made to make these results more explicit (Figure 3).

The temperatures are between $25{ }^{\circ} \mathrm{C}$ and $37{ }^{\circ} \mathrm{C}$. The $\mathrm{pH}$ ranges from 6.69 to 8.40 . We notice that the contents in oxygen dissolved in sampling taken from no Acadja side are under $3 \mathrm{mg} / \mathrm{L}$ contrary to those parameters such as temperature, $\mathrm{pH}$, dissolved oxygen were measured in situ by Multiparameter/ox-meter-WTW-340i. The measurement of suspended solids and level in $\mathrm{NO}_{3}{ }^{-}$and $\mathrm{NO}_{2}^{-}$is made by Methods 8006 with the colorimeter HACH DR/2000.

collected from Acadja side. The contents of nitrite and nitrate are around $3 \mathrm{mg} / \mathrm{L}$ in water taken from no Acadja side whereas they are high in water of Acadja side. Although, there is minor difference between weight and length of fishes taken from Acadja water and no Acadja water, it is necessary to mention that investigation made among the riverside habitants revealed that the weight of the fishes is reducing drastically from year to year.

Table 1: Physico-chemical parameters of water in Acadja side and in No Acadja side.

\begin{tabular}{|c|c|c|c|c|c|c|c|c|c|c|}
\hline & Samples & pH & Temperature & $\begin{array}{c}\text { Dissolved } \\
\text { oxygen } \\
\text { (mg/L) }\end{array}$ & $\begin{array}{l}\text { Supended } \\
\text { solids }\end{array}$ & $\begin{array}{c}\text { Turbidity } \\
\text { (NTU) }\end{array}$ & $\begin{array}{c}\mathrm{NO}_{3}^{-} \\
(\mathrm{mg} / \mathrm{L})\end{array}$ & $\begin{array}{c}\text { Weight } \\
\text { of } \\
\text { fish }(g)\end{array}$ & $\begin{array}{l}\text { Lenth of } \\
\text { fish(mm) }\end{array}$ & $\begin{array}{c}\mathrm{NO}_{2}^{-} \\
(\mathrm{mg} / \mathrm{L})\end{array}$ \\
\hline \multirow{4}{*}{$\begin{array}{l}\text { No } \\
\text { Acadja } \\
\text { side }\end{array}$} & 1 & 6,69 & 37 & 3,75 & 12,25 & 7 & 2,75 & 10,2 & 8,2 & 2 \\
\hline & 2 & 6,72 & 36 & 3,45 & 14,75 & 5 & 2,5 & 12,5 & 9,75 & 3 \\
\hline & 3 & 6,84 & 35 & 3,7 & 23 & 10 & 1,5 & 15,5 & 12,85 & 4,25 \\
\hline & Average & 6,75 & 36 & 3,63 & 16,66 & 7,33 & 2,25 & 12,73 & 10,26 & 3,08 \\
\hline \multirow{4}{*}{$\begin{array}{l}\text { Acadja } \\
\text { side }\end{array}$} & 4 & 8,1 & 29 & 2,77 & 40,12 & 25 & 8,5 & 11,5 & 7,75 & 7,15 \\
\hline & 5 & 8,4 & 25 & 1,65 & 37,06 & 40 & 10,5 & 13,25 & 8,95 & 5,83 \\
\hline & 6 & 8,3 & 27 & 1,8 & 29,56 & 36 & 7,25 & 14,75 & 12,75 & 5,9 \\
\hline & Average & 8,26 & 27 & 2,07 & 35,58 & 33,66 & 8,75 & 13,16 & 9,81 & 6,29 \\
\hline
\end{tabular}




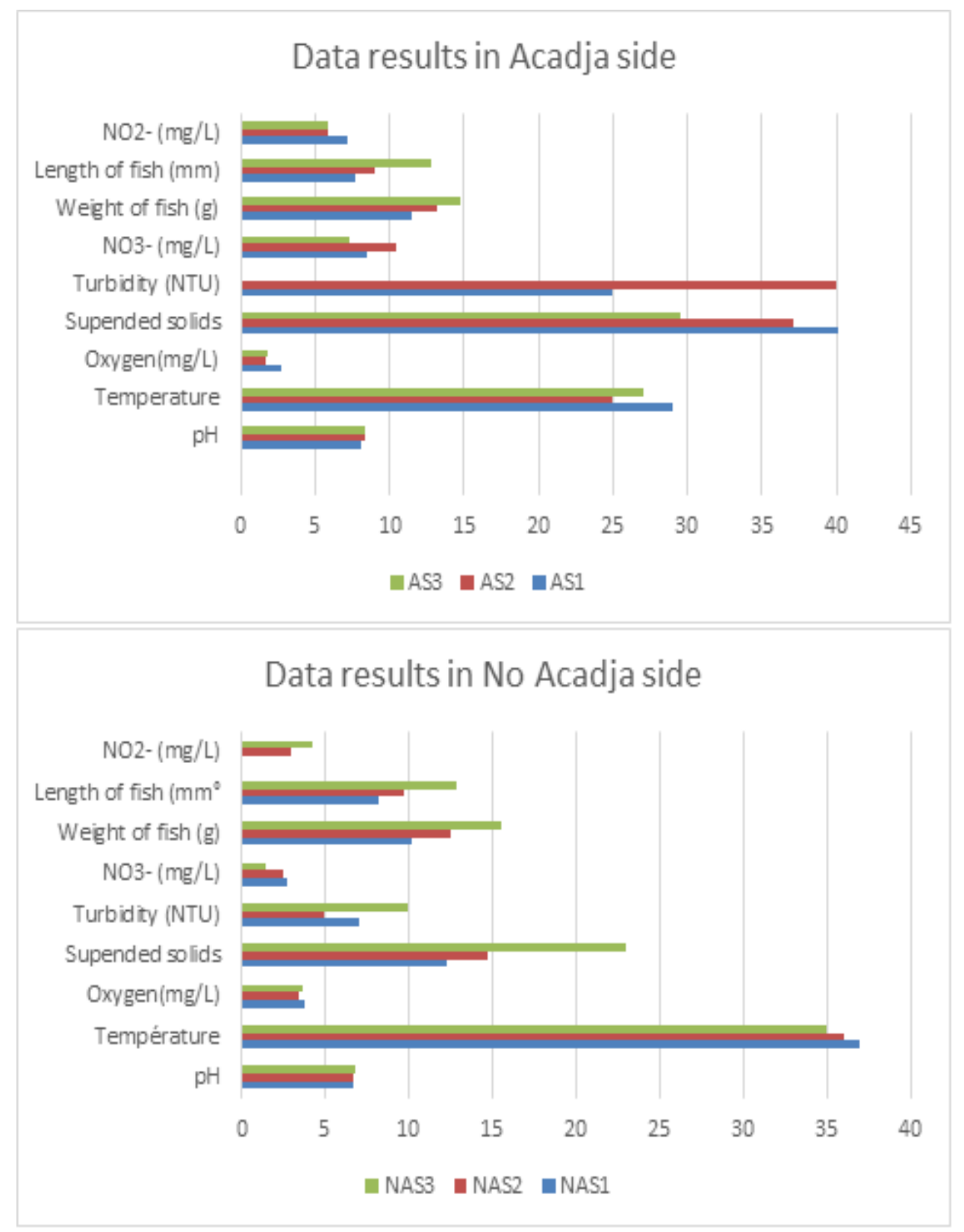

Figure 3: Data results in No Acadja side and data results in Acadja side.

\section{DISCUSSION}

According to Dovonou et al. (2011), the values of $\mathrm{pH}$ and temperatures are good for fish farming. They are good conditions of growth of the fish species. In case the $\mathrm{pH}$ values are not included in 6.5 to 9 , then there are potential risks of negative chronic effects in long terms for the aquatic life protection (Dovonou et al., 2011). We notice that the contents in oxygen dissolved in sampling taken from Acadja water fluctuate between 1.8 and $2.77 \mathrm{mg} / \mathrm{L}$. This decrease of dissolved oxygen and increase of suspended solids, turbidity and level in $\mathrm{NO}_{3}^{-}$and $\mathrm{NO}_{2}^{-}$ 
are no good for fish farming because such water is polluted. This will explain our investigation that revealed that the weight of the fishes is reducing drastically year to year in the Acadja stations. In fact, the dissolved oxygen is an essential ecological factor and plays an essential role in the preservation of the aquatic life (Baran, 1999). The oxygen dissolved contents in natural waters are mainly determined by the breath of the aquatic bodies, the oxidation, the degradation of pollutants, the photosynthetic activity of the flora and the exchanges with the atmosphere (Dedjiho et al., 2013). According to certain authors, the quality of this lake is classified in the mediocre range because the content in dissolved oxygen is lower than 3 $\mathrm{mg} / \mathrm{L}$. We deduct from this that the Acadja asphyxiate the lake and therefore fauna aquatic. The suspended solids include all the substances which are not dissolved. Their harmful effect due to formation of sediments and of a screen preventing the good penetration of the solar radiation (reduction of the photosynthesis) on the one hand (Laleye, 2010) and the clogging of the fish's gills on the other hand. Their effect is also chemical by constitution of a potential reserve of pollution in sediments. The biodegradable suspended solids contribute in a significantly to the oxygen demand and cause therefore the decrease of the concentration in oxygen dissolved in the aquatic environment. The suspended solids can asphyxiate some aquatic species and even the whole aquatic environment when they are present in excess, or to provoke momentary anoxia (Lalèyè, 1995). There are risks of long-term fatal chronic effects for the aquatic life protection if the value exceeds $5 \mathrm{mg} / \mathrm{L}$. Furthermore, the higher the temperature and the dissolved oxygen are, the higher the micro-organisms decompose organic materials (the branches tons into the lake). This is also the reason for the high turbidity observed. All this explain why the weight of the fishes is more and more reduced from year to year in the Acadja stations. Only the sensitization sessions are required to lead local people to adhere to sustainable resource management. In fact, the practice of Acadja is a very old and widespread traditional fishing method observed in Benin's lakes and lagoons. But, since several years, it is more and more forbidden by public authorities through the law $\mathrm{N}^{\circ} 152$ /MAEP of September $16^{\text {th }}$, 1970 , concerning removal of Acadja from the Nokoue lake, the lagoons of Porto-Novo.

\section{Conclusion}

This study which we have just carried out reveals that the dissolved oxygen, which is one of the key factors of aquatic life becomes scarce because it is much more requested for the decomposition of tons of discharge woods in the Nokoué Lake due to Acadja practice to fish. Therefore, water around Acadja area is polluted and is no longer adequate for fish farming. This explains why the weight of the fishes is reducing day by day in the Acadja station on Nokoue Lake. So the restoration of this aquatic ecosystem by forbidding the use of the traditional fishing practice named Acadja should be considered.

\section{COMPETING INTERESTS}

The authors declare that they have no competing interests about this paper.

\section{AUTHORS' CONTRIBUTIONS}

All the authors contributed to the study. They also participated in the writing and reading of the manuscript.

\section{ACKNOWLEDGMENTS}

Authors want to thank the Laboratoire des Sciences et Technique de l'Eau (LSTE), at National Institute of Water of Abomey-Calavi, University in Benin Republic. 


\section{REFERENCES}

Agonkpahoun E. 2006. Evaluation de la pollution des eaux continentales par les métaux toxiques : Cas de la rivière Okpara et du lac Nokoué au Bénin. Mémoire de Doctorat en Pharmacie, FSS /UAC, 87 P.

Amouzoun E. 2009. Initiatives d'assainissement local des déchets solides urbains et persistance de l'insalubrité dans le sixième arrondissement de Cotonou (Bénin): jeux d'acteurs et logique d'orientation stratégique de la mairie. Université d'Abomey-Calavi (UAC) - Maitrise de sociologie-anthropologie, 99p.

Baran E. 1999. Rôle des estuaires vis-à-vis de la ressource halieutique côtière en Guinée. In La Pêche Côtière en Guinée : Ressources et Exploitation, Domain F, Chavance P, Diallo A (eds). CNSHB; IRD : Boussoura (GIN), Paris ; 137-157.

Dedjiho CA, Mama D, Dimon BF, Chouti W, Alassane A, Fiogbe ED, Sohounhloue CKD. 2013. Influence de l'état d'eutrophisation de la lagune de Gbèzoumè (Ouidah) sur sa faune aquatique. Int. J. Biol. Chem. Sci., 7: 2069-2077.

Djogbénou E. 2019. Bénin - Assainissement des plans d'eau : le lac Ahémé débarrassé des « acadja », Dossier Environnement de Benin Web Archves Tv du 16 Août 2019.

Dovonou F. 2008. La pollution des plans d'eau au Bénin. Université d'Abomey-calavi (Bénin) - DEA en Environnement, Santé et Développement, 70p.

Dovonou F, Aïna M, Alassane AMB. 2011. Pollution physico-chimique et bactériologique d'un écosystème aquatique et ses risques écotoxicologiques: Cas du lac Nokoué au Sud Bénin. International Journal of Biological and Chemical Sciences, 5: 1590-1602.

DOI: http://dx.doi.org/10.4314/ijbcs.v5i4.23

Lalèyè P. 2010. Biodiversité et exploitation des ressources vivantes aquatiques du Bénin : état des lieux. Revue Scientifique du CBRST. 2010.

Lalèyè PA. 1995. Ecologie comparée de deux espèces de Chrisichthys, poissons siluriformes (Claroteidae) du complexe lagunaire lac Nokoué-lagune de PortoNovo au Bénin. Thèse de Doctorat en Sciences, Université de Liège, Belgique. 